\title{
Isotopic studies of marbles in the Sanbagawa metamorphic terrain, central Shikoku, Japan
}

\author{
HIDEKI WADA ${ }^{1}$, MASAKI ENAMI ${ }^{2}$ and TAKERU YANAGI ${ }^{3}$ \\ Institute of Geosciences, Faculty of Science, Shizuoka University, Shizuoka $422^{1}$, \\ Department of Earth Sciences, Faculty of Science, Nagoya University, Chikusa, Nagoya $464^{2}$ \\ and Department of Geology, Faculty of Science, Kyushu University, Fukuoka $812^{3}$ Japan
}

(Received November 12, 1983: Accepted February 29, 1984)

\begin{abstract}
Carbon, oxygen and strontium isotopic studies were carried out on marbles occurring in crystalline schists and epidote amphibolites of the Sanbagawa metamorphic terrain, central Shikoku, Japan, in order to estimate metamorphic temperatures and to elucidate their origin. Carbon isotopic fractionation between calcite and graphite shows the metamorphic temperature of $460^{\circ} \mathrm{C}$ at the transitional part between the garnet and albite-biotite zones.

Marbles are isotopically classified into two groups. (1) some marbles in epidote amphibolite masses show characteristically negative $\delta^{13} \mathrm{C}$ values and low ${ }^{87} \mathrm{Sr} /{ }^{86} \mathrm{Sr}$ ratios. These marbles are interpreted as have been derived from magmatic or deep-seated carbonates. (2) marbles collected from the crystalline schists and from the marginal part of epidote amphibolite masses, have high ${ }^{87} \mathrm{Sr} /{ }^{86} \mathrm{Sr}$ ratios and $\delta^{13} \mathrm{C}$ values similar to those of typical sedimentary carbonates. They were probably derived from sedimentary carbonates and/or carbonates re-equilibrated with metamorphic fluid segregated from crystalline schists during the Sanbagawa metamorphism.
\end{abstract}

\section{INTRODUCTION}

Graphite-bearing marbles occur commonly in many regional and contact metamorophic terrains in the world. Carbon isotopic fractionation between calcite and graphite has been reported from several localities of various grades of metamorphism (WADA and OANA, 1975; PINEAU et al., 1976; HoEfs and Frey, 1976; WADA, 1977; VAlleY and O'NeIL, 1981; WADA and SUZUKI, 1983). The temperature dependence of carbon isotopic fractionation between calcite and graphite was estimated by BoTTINGA (1969) on the basis of theoretical calculations for a temperature range from 0 to $700^{\circ} \mathrm{C}$. VALLeY and O'NeIL (1981) and WADA and SUZUKI (1983) showed that the carbon isotopic geothermometer, using calcite-graphite pairs, is useful for the determination of metamorphic temperature in medium- to high-grade zones.

DEINES and GoLD (1973) suggested that magmatic or deep-seated carbonates have $\delta^{13} \mathrm{C}$ values distinctly lower than those of marine carbonates. HoEFs (1980) reviewed stable isotopic studies of carbonates from various geological settings and concluded that carbon isotopic composition is useful to reveal the origin of carbonates.

Strontium isotopic studies as well as carbon and oxygen isotopic studies would provide powerful constraints on any viable theories of petrogenesis of marbles.

Twenty-two marbles were collected from crystalline schists and epidote amphibolites of the Sanbagawa metamorphic terrain, central Shikoku, Japan. Petrogenesis of the epidote amphibolite masses of this area has been discussed by many authors. These masses were once considered to represent massive and coarse-grained parts of metavolcanic sequence (basic schists) (e.g., HIDE, 1961; BANNO, 1964). One of the main bases of their arguments is that some marbles are intercalated concordantly within the epidote amphibolite masses. They 
considered that marbles in the epidote amphibolite masses are sedimentary in origin. These masses, however, are now believed to have been emplaced as solid bodies in the Sanbagawa terrain from the lower crust or the upper mantle and subjected to the Sanbagawa metamorphism later (e.g., BANNO et al., 1976; YoKoYAMA, 1980). If so, as pointed out by BANNO et al. (1976), the origin of the marble remains unsolved.

The present study is intended to estimate metamorphic temperatures of some graphite bearing marbles in the Sanbagawa metamorphic terrain, central Shikoku, Japan, applying the carbon isotopic geothermometer, and to elucidate the origin of marbles, especially of those in epidote amphibolites by means of carbon, oxygen and strontium isotopic compositions.

\section{OUTLINE OF GEOLOGY AND PETROGRAPHY}

The Sanbagawa metamorphic terrain of central Shikoku is a part of the typical intermediate high-pressure metamorphic belt in Japan (MrYASHIRO, 1961). On the basis of mineral parageneses in pelitic schists, BANNO et al., (1978) and ENAMI (1982, 1983) have divided the metamorphic terrain into four mineral zones; chlorite, garnet, albite-biotite and oligoclase-biotite zones, with increasing metamorphic grade. Figure 1 shows the metamorphic zonation with sampling localities. In the Sanbagawa terrain, marbles occur as thin layers or in lenticular form (less than $1 \mathrm{~m}$ in width) in epidote amphibolites and crystalline schists. Marbles examined in this study were collected from such layers or beds. Samples are from the following four rock types; pelitic schist, epidote amphibolite, basic schist and quartz schist

Marbles in pelitic schists were collected from the Hadeba (samples PS01 PS05), Fujiwara (sample PS06) and Matsuno (samples PS07 PS08) areas. Mg-Fe partition coefficient between garnet and chlorite $\left(\mathrm{K}_{\mathrm{Mg}-\mathrm{Fe}}^{\mathrm{Ga}-\mathrm{Chl}}\right)$ is 0.070 in the pelitic schists from the Hadeba area and 0.072 in the rocks from the Fujiwara area (EnAmI, 1980). These values correspond to the higher grade part of the garnet zone or the transitional part between the garnet and albitebiotite zones (see Higashino, 1975). Taking into account the $\mathrm{K}_{\mathrm{Mg}-\mathrm{Fe}}^{\mathrm{Ga}-\mathrm{Chl}}$ values and local occurrences of biotite flakes in host pelitic schists of the marbles (BANNO, 1964; HigaSHINO et al., 1977; ENAMI, 1980), we deduce that the Hadeba and Fujiwara areas belong to the higher-grade part of the garnet zone or the transitional part between the garnet and albite-biotite zones. In both areas, marbles occur in lenticular form (3-40 cm in width, Fig. 2 a) and show a banded structure with the alternation of graphite-rich and -poor layers (Fig. 2b).

The Matsuno marble occurs as a block (about $1 \mathrm{~m}$ across) on a river bed of the River Dozan. Although the Matsuno area lies in the transitional part between garnet and albitebiotite zones, the marble block itself might probably have been derived from the albitebiotite or oligoclase-biotite zone, since siliceous part of the block contains biotite as a major constitutent mineral.

Except the Fujiwara sample (PS06), the marbles are composed mainly of calcite, graphite, diopside, tremolite and zoisite with subordinate amounts of chlorite, muscovite, albite, quartz and sphene. The sample PS06 has a mineral assemblage of calcite+graphite+paragonite+ muscovite+zoisite+albite+quartz+sphene.

Marbles in epidote amphibolites (samples EA01 EA08) were collected from the Iratsu and Tonaru masses. These masses are metamorphosed layered gabbro complexes, which were subjected to the Sanbagawa metamorphism of the epidote amphibolite facies (BANNO et al., 1976; TAKASU and MAKINO, 1980; YoKoYAMA, 1980). Samples EA01 EA04 and EA05 EA08 belong to the oligoclase-biotite and albitebiotite zones, respectively. These marbles occur in lenticular form (about $1 \mathrm{~m}$ maximum in width) intercalated concordantly or subconcordantly in the host epidote amphibolite (Fig. 

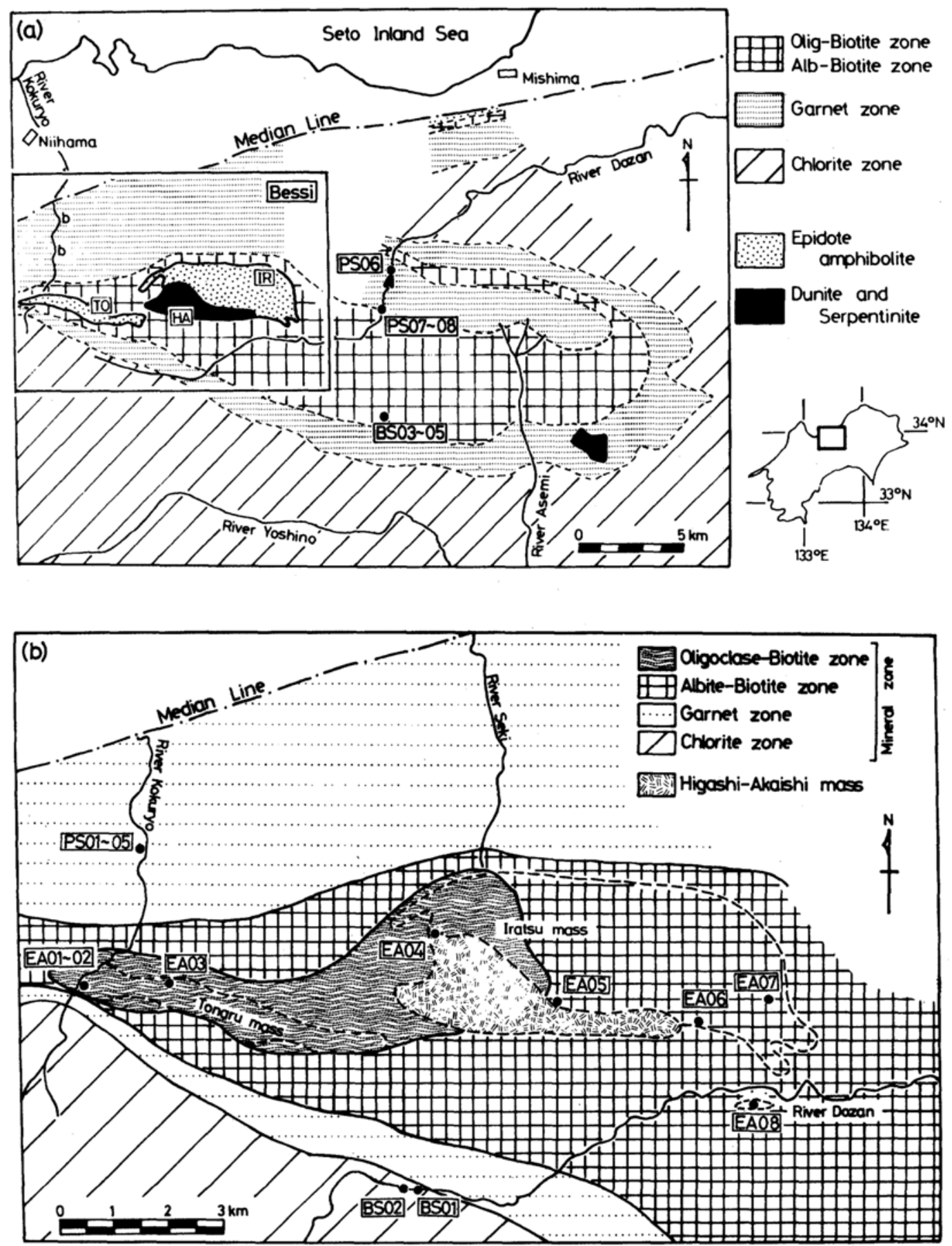

Fig. 1 Metamorphic zonation maps with sample localities. For the locality of sample QSO1, see the text.

(a) Central Shikoku (after BANNO et al., 1978). The mark " $b$ " denotes the area where biotite-bearing pelitic schists occur, see the text. TO: Tonaru mass, HA: Higashi-Akaishi mass, IR: Iratsu mass. Sample localities of the Bessi area are shown in an enlarged map of Fig. 1(b).

(b) Bessi area (after ENAMI, 1982). Broken line shows the lithologic boundary between dunite-epidote amphibolite complex and the surrounding crystalline schists. 

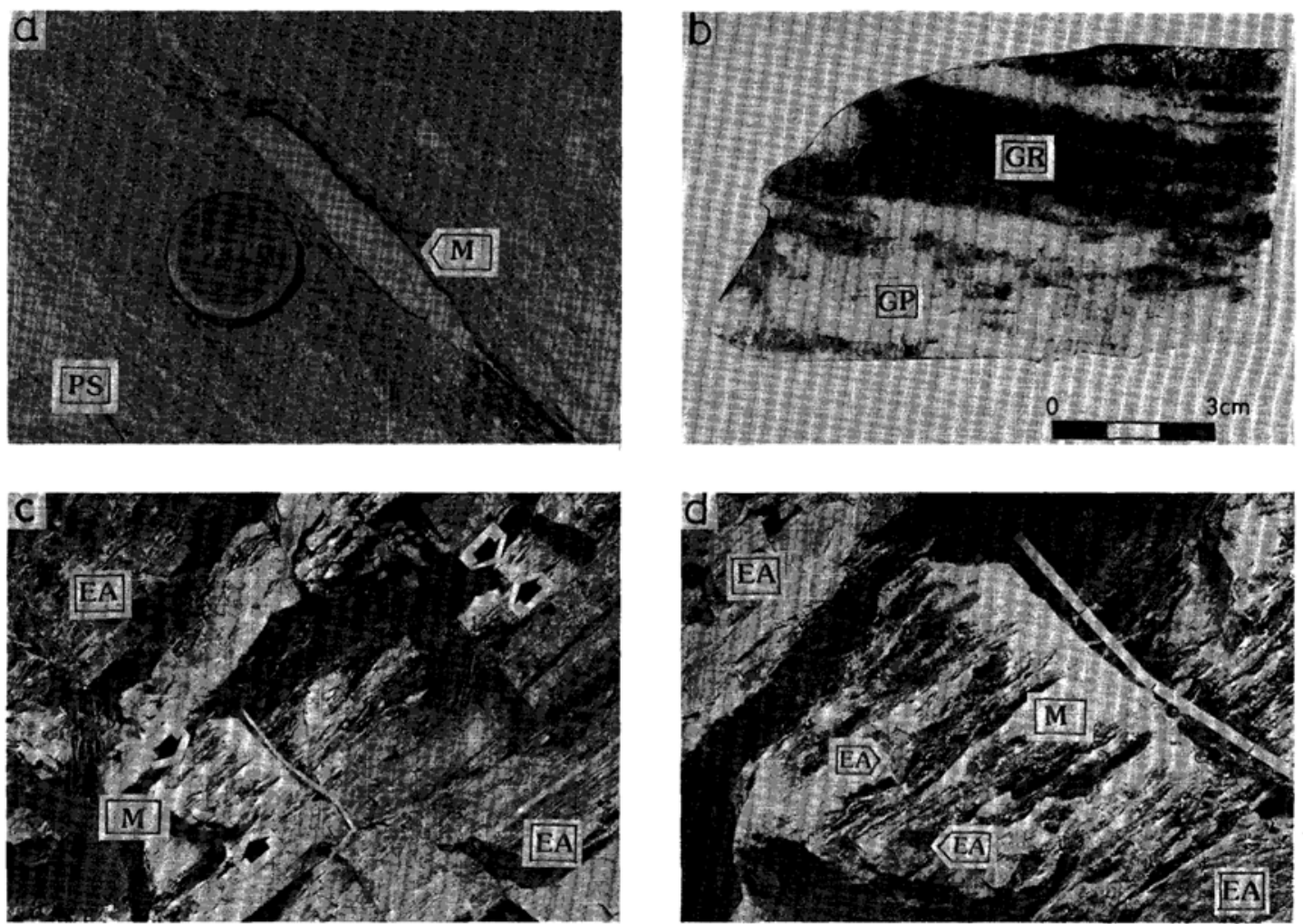

Fig. 2 Mode of occurrence of some selected marbles.

(a) A lenticular marble in the pelitic schist of the Fujiwara area.

(b) Polished surface of a marble in the pelitic schist of the Matsuno area.

(c) A marble layer in the Tonaru epidote amphibolite mass. Arrows indicate the boundary between the marble and the epidote amphibolite.

(d) Close up view of the lower left part in (c). Small chips of epidote amphibolite are observed in the marble layer.

M: marble, EA: epidote amphibolite, PS: pelitic schist, GR: graphite-rich layer, GP: graphite-poor layer.

2 c), and usually contain small chips (about $10 \mathrm{~cm}$ maximum across) of epidote amphibolite (Fig. 2 d). These marbles are composed mainly of calcite, diopside, hornblende and epidote with subordinate amounts of chlorite, muscovite, albite, quartz and sphene. Sample EA08 contains grossular in addition to these minerals.

Marbles in basic schists were taken from the Shirataki (samles BS03 BS05) and Otoji (samples BS01 BS02) areas. The Shirataki marble occurs in the Shirataki Dai-ichi amphibolite of HIDE (1954) in irregular or lenticular form (about $1 \mathrm{~m}$ maximum in width) subparallel to the schistosity (HIDE, pers. com., 1980). The Shirataki amphibolite is a massive and coarse- grained basic schist. It is apparently similar to the metamorphosed layered gabbros of the Iratsu and Tonaru masses, but is considered to be metamorphosed basaltic tuff or hyaloclastite (KAWACHI et al., 1973, 1982; WATANABE and KAWACHI, 1975). Typical mineral assemblage of the Shirataki amphibolite is hornblende + epidote + chlorite + muscovite + albite + quartz (HIDE, 1954), suggesting the metamorphic grade of the albite-biotie zone. Except the sample BS05, the Shirataki marbles have a mineral assemblage of calcite+epidote+chlorite+ muscovite+albite+quartz+sphene. The sample BS05 contains diopside and hornblende in addition to the above assemblage. 
The Otoji samples belong to a higher-grade part of the chlorite zone. They occur as veins (about $0.5-2 \mathrm{~cm}$ in width) cutting the schistosity of the host basic schists, and contains calcite, epidote, chlorite, stilpnomelane, albite and quartz.

Marble in quartz schist (sample QS01) was collected in the Bessi mine about 1,500m below the sea level (point 15SL) (HIDE, pers. com. 1980). The host rock consists mainly of subcalcic hornblende, garnet, epidote, chlorite, muscovite, albite and quartz. Its metamorphic grade is of the garnet zone. The marble contains calcite, diopside, tremolite, epidote and subordinate amounts of muscovite, albite, quartz and sphene.

\section{SAMPLES AND EXPERIMENTS}

Carbonaceous matter is observed in all marbles occurring in pelitic schists. When marble has some obscure beddings or strips, graphite is concentrated mostly in the darker part. In order to know the isotopic variation in a sample, isotopic analyses were carried out on two or three splits of a fist-size marble. Isotopic compositions of calcite and graphite are averages for such splits with a size of $3 \mathrm{~cm} X$ $5 \mathrm{~cm} \times 1 \sim 2 \mathrm{~cm}$.

The carbon and oxygen isotopic compositions are reported in the $\delta$-notation relative to PDB (Craig, 1957) and SMOW (Craig, 1961), respectively.

$$
\begin{aligned}
& \delta(\% \circ)=(\mathrm{R}(\text { sample }) / \mathrm{R}(\text { standard })-1) \\
& \quad \times 1,000
\end{aligned}
$$

where $\mathrm{R}$ is ${ }^{13} \mathrm{C} /{ }^{12} \mathrm{C}$ or ${ }^{18} \mathrm{O} /{ }^{16} \mathrm{O}$ in a sample and the standard. The working standard was calibrated with respect to NBS-20 (CraIG, 1957). The relationship between $\mathrm{PDB}$ and SMOW standard on the $\delta^{18} \mathrm{O}$ value of calcite was adopted from FrIEDMAN and O'NeIL (1977).

The carbon isotopic fractionation factor $\alpha$ between calcite and graphite is defined as follows;

$$
\alpha_{\mathrm{Cc}-\mathrm{Gr}}=\left({ }^{13} \mathrm{C} /{ }^{12} \mathrm{C}\right)_{\mathrm{Cc}} /\left({ }^{13} \mathrm{C} /{ }^{12} \mathrm{C}\right)_{\mathrm{Gr}}
$$

where subscripts $\mathrm{Cc}$ and $\mathrm{Gr}$ stand for calcite and graphite, respectively. Since $\alpha$ is very close to unity,

$$
\begin{gathered}
1,000 \ln \alpha_{\mathrm{Cc}-\mathrm{Gr}}=\Delta^{13} \mathrm{C}_{\mathrm{Cc}-\mathrm{Gr}} \\
\doteq \delta^{13} \mathrm{C}_{\mathrm{Cc}}-\delta^{13} \mathrm{C}_{\mathrm{Gr}}
\end{gathered}
$$

Calcite was reacted with $100 \%$ phosphoric acid at $25^{\circ} \mathrm{C}$ (MCCREA, 1950).

Graphite was separated from carbonate with hydrochloric acid. An aliquot of several milligrams of carbon was burnt to $\mathrm{CO}_{2}$ in oxygen atmosphere at $950^{\circ} \mathrm{C}$. The carbon dioxide was purified and then analyzed with a Nier-McKinney type dual collector mass-spectrometer, Varian Mat $\mathrm{CH}-7$, at Department of Earth Sciences, Nagoya University.

Replicate analyses were made on many samples, and errors quoted in Tables 1 and 2 indicate the average deviation from the mean. However, no estimate for error was given when only single analysis was made.

Strontium isotopic measurements were made with a $30 \mathrm{~cm}, 90$ degrees solid source massspectrometer JEL-05RB at Department of Geology, Kyushu University. $\mathrm{Rb}$ and $\mathrm{Sr}$ concentrations were determined by isotopic dilution method using strontium-84 and rubidium- 87 spikes and the ${ }^{87} \mathrm{Sr} /{ }^{86} \mathrm{Sr}$ ratio was determined separately on unspiked samples. The ${ }^{87} \mathrm{Sr} /{ }^{86} \mathrm{Sr}$ ratio of the $\mathrm{E}$ and $\mathrm{A}_{\mathrm{SrCO}_{3}}$ standard was measured to be 0.7080 . The uncertainty in Tables 1,2 and 5 are at 2 sigma level.

Degree of graphitization was confirmed of four samples with a X-ray powder diffractometer of Rigaku Denki Co., Ltd. at Department of Earth Sciences, Nagoya University under the following conditions; $\mathrm{Cu}-\mathrm{K} \alpha, 35 \mathrm{kv}, 15 \mathrm{~mA}, \mathrm{Ni}$ filter, slit 1-0.15-1 degree and scanning rate $1 / 8$ deg./min. Silicon was used as the internal standard. The results were shown in Table 3 . The spacing $d(002)$ and the crystallite thickness Lc (002) are 3.35-3.36 $\AA$, and 622-714 $\AA$, respectively, showing that the carbonaceous matter belongs to fully ordered graphite of 
Table 1. Isotopic compositions of graphite and calcite in marbles collected from pelitic schists of the Sanbagawa metamorphic terrain, central Shikoku.

\begin{tabular}{|c|c|c|c|c|c|c|c|c|c|}
\hline \multirow{3}{*}{$\begin{array}{l}\text { Sample } \\
\text { No. }\end{array}$} & \multirow{3}{*}{ Locality } & \multicolumn{2}{|c|}{ Calcite } & \multirow{2}{*}{$\begin{array}{c}\text { Graphite } \\
\delta^{13} \mathrm{C}\end{array}$} & \multirow{2}{*}{$\begin{array}{l}\triangle^{13} \mathrm{C} \\
\mathrm{Cc}-\mathrm{Gr}\end{array}$} & \multirow{2}{*}{$\begin{array}{c}\text { Metamorphic } \\
\text { temperature }\end{array}$} & \multirow{2}{*}{$\begin{array}{c}\text { Acid } \\
\text { insoluble } \\
\text { residue }\end{array}$} & \multirow{2}{*}{$\begin{array}{l}\text { Graphite } \\
\text { content }\end{array}$} & \multirow{3}{*}{${ }_{\text {ratio }}^{{ }^{87} \mathrm{Sr} /{ }^{86} \mathrm{Sr}}$} \\
\hline & & $\delta^{18} \mathrm{O}$ & $\delta^{13} \mathrm{C}$ & & & & & & \\
\hline & & SMOW, \%० & PDB, \%० & PDB, \%० & $\% \circ$ & ${ }^{\circ} \mathrm{C}$ & $\%$ & $\%$ & \\
\hline PS01 & Hadeba & $+14.5 \pm 0.4$ & $+0.4 \pm 0.1$ & $-7.9 \pm 0.1$ & +8.3 & 450 & 2.1 & 0.06 & \\
\hline PSO2a & Hadeba & $+15.7 \pm 0.1$ & $+1.9 \pm 0.0$ & -6.5 & +8.4 & 450 & 1.1 & 0.14 & \\
\hline PSO2b & Hadeba & +15.6 & +2.0 & $-6.3 \pm 0.1$ & +8.3 & 450 & 1.6 & 0.07 & \\
\hline PS03a & Hadeba & +15.2 & +1.3 & -8.1 & +9.4 & 420 & 0.4 & 0.01 & \\
\hline PS03b & Hadeba & +15.1 & +1.4 & $-7.9 *^{1}$ & +9.3 & 430 & 0.9 & 0.03 & \\
\hline PS04a & Hadeba & +15.3 & +1.9 & $-7.4 *^{2}$ & +9.3 & 430 & 1.5 & 0.03 & \\
\hline PS04b & Hadeba & +15.3 & +1.8 & $-7 . *^{* 3}$ & +9.3 & 430 & 0.6 & 0.03 & \\
\hline PS05 & Hadeba & +15.2 & +2.1 & $-7.0 \pm 0.3$ & +9.1 & 430 & 2.5 & 0.07 & $0.70705 \pm 0.00016$ \\
\hline PS06a & Fujiwara & $+15.4 \pm 0.1$ & $-1.0 \pm 0.2$ & $-9.2 \pm 0.0$ & +8.2 & 460 & 0.6 & 0.01 & \\
\hline PS06b & Fujiwara & +15.5 & -1.6 & $-9.9 \pm 0.1$ & +8.3 & 450 & 0.5 & 0.01 & \\
\hline PS07a & Matsuno & $+14.7 \pm 0.0$ & $+2.0 \pm 0.1$ & $-5.8 \pm 0.1$ & +7.8 & 470 & 1.3 & 0.08 & \\
\hline PS07b & Matsuno & +14.6 & +0.7 & $-6.7 \pm 0.0$ & +7.4 & 480 & 3.5 & 0.13 & \\
\hline PS07c & Matsuno & +14.5 & +0.8 & $-6.8 \pm 0.2$ & +7.6 & 480 & 1.2 & 0.01 & \\
\hline PS08a & Matsuno & $+14.7 \pm 0.0$ & $+0.1 \pm 0.1$ & -7.6 & +7.7 & 470 & 0.7 & 0.01 & $0.70804 \pm 0.00024$ \\
\hline PS08b & Matsuno & +14.8 & +0.5 & $-6.6 \pm 0.1$ & +7.1 & 500 & 0.5 & 0.02 & \\
\hline
\end{tabular}

${ }^{* 1}(-7.2,-7.6,-8.0,-8.8),{ }^{* 2}(-6.1,-7.5,-8.6),{ }^{* 3}(-5.8,-7.7,-8.2,-8.2)$, the ${ }^{13} C$ value in this Table shows the average value.

Table 2. Whole-rock isotopic compositions of marbles collected from the Sanbagawa metamorphic terrain, central Shikoku.

\begin{tabular}{lllrrr} 
Sample No. & \multicolumn{1}{c}{ Locality } & \multicolumn{1}{c}{ Host rock type } & \multicolumn{1}{c}{${ }^{18} \mathrm{O}$} & $\delta^{13} \mathrm{C}$ & ${ }^{87} \mathrm{Sr}{ }^{86} \mathrm{Sr}$ ratio \\
& & & SMOW, \%० & PDB, \%० & \\
& & & & & \\
EA01 & Tonaru mass & Epidote amphibolite & +13.0 & +2.8 & $0.70697 \pm 0.00018$ \\
EA02 & Tonaru mass & Epidote amphibolite & +12.9 & +2.8 & \\
EA03 & Tonaru mass & Epidote amphibolite & +12.1 & +1.6 & \\
EA04 & Iratsu mass & Epidote amphibolite & +12.9 & -4.3 & $0.70522 \pm 0.00018$ \\
EA05 & Iratsu mass & Epidote amphibolite & +8.6 & -8.9 & \\
EA06 & Iratsu mass & Epidote amphibolite & +17.1 & +2.6 & $0.70664 \pm 0.00010$ \\
EA07 & Iratsu mass & Epidote amphibolite & +10.8 & -5.1 & \\
EA08 & Iratsu mass & Epidote amphibolite & +11.7 & +2.7 & \\
BS01 & Otoji & Basic schist & +15.5 & +1.9 & \\
BS02 & Otoji & Basic schist & +10.3 & -0.2 & \\
BS03 & Shirataki mine & Basic schist & +13.6 & +2.0 & \\
BS04 & Shirataki mine & Basic schist & +14.0 & +1.9 & \\
BS05 & Shirataki mine & Basic schist & +14.4 & +1.3 & \\
QS01 & Bessi mine & Quartz schist & +22.1 & +1.6 & $0.70731 \pm 0.00016$
\end{tabular}

Table 3. The degree of graphitization of some selected carbonaceous matter in marbles of the Sanbagawa metamorphic terrain, central Shikoku.

\begin{tabular}{llcccc} 
Sample No. & Locality & $\mathrm{d}(002) \AA$ & Lc(002) $\AA$ & \multicolumn{2}{c}{ D.G.* } \\
& & & & $(1)$ & $(2)$ \\
PS04 & Hadeba & 3.35 & 635 & FO & FG \\
PS05 & Hadeba & 3.35 & 714 & FO & FG \\
PS06a & Fujiwara & 3.35 & 687 & FO & FG \\
PS06b & Fujiwara & 3.35 & 622 & FO & FG \\
PS07a & Matsuno & 3.35 & 654 & FO & FG \\
PS07b & Matsuno & 3.36 & 653 & FO & FG
\end{tabular}

*Degree of graphitization. (1): LANDIS (1971), (2): TAGIRI and TSUBOI (1979). 
Table 4. Magnesite and siderite components in calcite of marbles from the Sanbagawa metamorphic terrain, central Shikoku.

\begin{tabular}{lrlrr}
\multicolumn{1}{c}{ Locality } & Sample No. & Host rock type & $\begin{array}{r}\text { Magnesite } \\
(\mathrm{mol} . \%)\end{array}$ & $\begin{array}{r}\text { Siderite } \\
\text { (mol. \%) }\end{array}$ \\
Tonaru & EA01 & Epidote amphibolite & $1.7 \pm 0.9$ & $0.6 \pm 0.2$ \\
& EA03 & Epidote amphibolite & $0.4 \pm 0.1$ & $0.2 \pm 0.1$ \\
Iratsu & EA06 & Epidote amphibolite & $1.9 \pm 0.6$ & $0.3 \pm 0.1$ \\
& EA08 & Epidote amphibolite & $<0.1$ & $<0.1$ \\
Hadeba & PS02 & Pelitic schist & $0.9 \pm 0.3$ & $<0.1$ \\
& PS05 & Pelitic schist & $0.8 \pm 0.4$ & $<0.1$ \\
Fujiwara & PS06 & Pelitic schist & $0.3 \pm 0.1$ & $0.3 \pm 0.2$ \\
Matsuno & PS07 & Pelitic schist & $0.4 \pm 0.2$ & $<0.1$ \\
Shirataki & BS04 & Basic schist & $1.8 \pm 0.2$ & $0.7 \pm 0.1$ \\
& BS05 & Basic schist & $0.3 \pm 0.3$ & $0.2 \pm 0.2$ \\
Bessi & QS01 & Quartz schist & $0.3 \pm 0.1$ & $0.3 \pm 0.1$
\end{tabular}

LANDIS (1971)'s classification or FG type of TAGIRI and TSUBOI (1979).

Chemical analyses of calcite were carried out on eleven samples by the method described by YUSA (1976) using JXA-5A electron microprobe analyzer of JEOL at Department of Earth Sciences, Nagoya University. The accelerating voltage, specimen current and beam diameter were kept at $15 \mathrm{kv}, 0.01 \mu \mathrm{A}$ and $20 \mu \mathrm{m}$, respectively. As shown in Table 4, calcite has little magnesite and siderite components. For other marbles, X-ray diffraction analyses show that calcite is the only carbonate present.

\section{REsults AND Discussion}

Carbon isotopic temperature Carbon isotopic compositions of calcite and graphite in marbles collected from pelitic schists are given in Table 1 with the carbon isotopic fractionation between them. The relationship between $\delta^{13} \mathrm{C}_{\mathrm{Cc}}$ and $\delta{ }^{13} \mathrm{C}_{\mathrm{Gr}}$ values is illustrated in Fig. 3 . The $\delta^{13} \mathrm{C}$ values of calcite range from -1.6 to $+2.1 \%$ and those of graphites from -9.9 to $-5.8 \%$ 。.

$\delta^{13} \mathrm{C}$ values of two subsamples of the Fujiwara marble are slightly scattered $(-1.0$ and $-1.6 \%$ o for calcite and -9.2 and $-9.9 \%$ 。 for graphite), but their $\Delta{ }^{13} \mathrm{C}_{\mathrm{Cc}-\mathrm{Gr}}$ values are identical $(+8.2$ and $+8.3 \%$ ) within analytical error. Two samples (PS07 and PS08) from the Matsuno area show $\Delta^{13} \mathrm{C}_{\mathrm{Cc}-\mathrm{Gr}}$ values from +7.1 to $+7.8 \%$ o (Table 1$). \quad \delta^{13} \mathrm{C}$ value of calcite of a subsample (PS07a) is $+2.0 \%$ o that is larger than the others (PS07b and c) by more than $1 \%$, but $\Delta^{13} \mathrm{C}_{\mathrm{Cc}-\mathrm{Gr}}$ values of these three are the same within analytical error. These results show that calcite and graphite in the Matsuno and Fujiwara samples, are in the carbon isotopic equilibrium, although isotopic heterogeneity seems to exist within a short distance (a few $\mathrm{cm})$.

As shown in Table 1, the Hadeba marble (PS01 05) has $\Delta^{13} \mathrm{C}_{\mathrm{Cc}-\mathrm{Gr}}$ values from +8.3 to $+9.4 \%$. Calcites in subsamples of the Hadeba marbles have the same $\delta^{13} \mathrm{C}$ values, showing

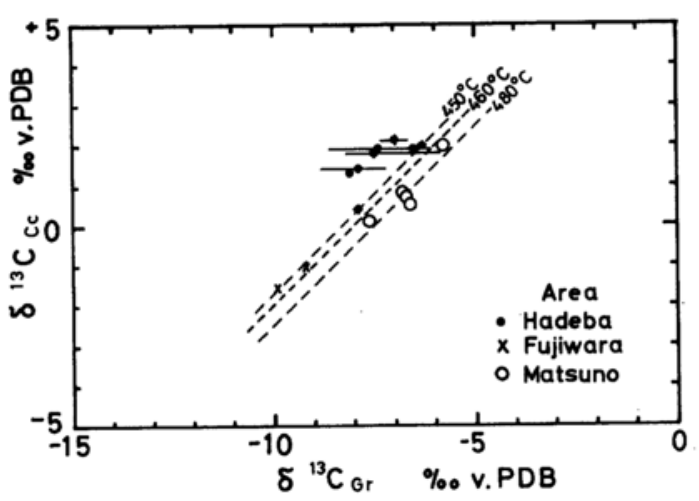

Fig. 3 Relationship between $\delta^{13} C_{C c}$ and $\delta^{13} C_{C r}$ values of the marble collected from pelitic schists in the Sanbagawa metamorphic terrain, central Shikoku. For the error bar of the Hadeba samples, see the text.

Dashed lines indicate the carbon isotopic fractionations at 450,460 and $480^{\circ} \mathrm{C}$, respectively given by $W A D A$ and SUZUKI (1983). 
that the carbon isotopic compositions of calcite is homogeneous within a sample. Two samples PSO1 and PS02 give the same $\Delta^{13} \mathrm{C}_{\mathrm{Cc}-\mathrm{Gr}}$ value of $+8.3 \%$. This seems to show that the carbon isotopic equilibrium was attained in both samples. Carbon isotopic analyses of PS03 05, however, show that there is a wide variation in $\delta^{13} \mathrm{C}$ values of graphite even within a hand specimen. For example, the replicate measurements show that $\delta^{13} \mathrm{C}$ values of graphite of PS3b fall in the range from -7.2 to $-8.8 \%$, scattering well over the range of analytical uncertainty. This isotope heterogeneity of graphite may be explained as follows; graphite in marbles of the Sanbagawa metamorphic terrain occurs usually as scattered aggregates of small graphite crystals enclosed in calcite grains or clustered along the boundary between crystal grains of calcite. Such dispersed graphite in marbles are considered to be biogenic carbon $\delta^{13} \mathrm{C}$ values of which might have been originally around $-25 \%$ 。 or lower (WADA and OANA, 1975). As listed in Table 1, calcite is predominant in marbles and the graphite content of marbles is mostly less than 0.1 weight percent. Therefore, it is considered that the carbon isotopic composition of graphite disproportionately become enriched in ${ }^{13} \mathrm{C}$ during the exchange reaction with calcite. In PS02, graphite occurs mostly in the boundary of calcite, but PSO4 marble has some crystals of graphite characteristically adhering to silicates or quartz. WADA and SUZUKI (1983) have reported a case in which graphite adhering to or being armored by silicates or quartz is enriched in ${ }^{12} \mathrm{C}$ in comparison with graphite coexisting only with calcite. In addition, the average $\Delta{ }^{13} \mathrm{C}_{\mathrm{Cc}-\mathrm{Gr}}$ value of PS03 05 is apparently larger than that of PSO1 and PS02, therefore the large $\triangle^{13} \mathrm{C}_{\mathrm{Cc}-\mathrm{Gr}}$ values of three Hadeba marbles (PSO3 $\sim 05$ ) could be explained in terms of the disequilibrium in the isotopic exchange reaction between calcite and graphite at the peak metamorphic temperature.

The metamorphic temperatures of these samples were estimated on the basis of the carbon isotopic geothermometer formulated by WADA and SUzUKI (1983) as follows;

$$
\begin{aligned}
& 1,000 \ln \alpha_{\mathrm{Cc}-\mathrm{Gr}} \\
& =5.6 \times 10^{6} \times \mathrm{T}^{-2}(\mathrm{~K})-2.4
\end{aligned}
$$

Results are listed in Table 1. The isotopic temperatures of the Matsuno marble are from 470 to $500^{\circ} \mathrm{C}$, averaging $480^{\circ} \mathrm{C}$. The temperature is calculated to be $460^{\circ} \mathrm{C}$ for the Fujiwara marble and $450^{\circ} \mathrm{C}$ for Hadeba marble (for PSO1 and PS02). As already described, the Hadeba and Fujiwara marbles are in the upper part of the garnet zone and/or in the transitional part between the garnet and albite-biotite zones, and the Matsuno marble is considered to have been derived from the albite-biotite zone or from the oligoclase-biotite zone. Therefore, the temperature at the boundary between the garnet zone and the albite-biotite zone is estimated to be between 450 and $480^{\circ} \mathrm{C}$, or most probably $460^{\circ} \mathrm{C}$ as shown in Fig. 3 .

TAYLOR and COLEMAN (1968) have determined the oxygen isotopic compositions of quartz and magnetite in a basic schist collected from the Shirataki mine, in central Shikoku, and reported that a compatible oxygen isotopic fractionation between quartz and magnetite is $+10.7 \%$. This value may give a metamorphic temperature of about $500^{\circ} \mathrm{C}$ when the quartzwater fractionation curve of CLAYTON et al. (1972) is combined with magnetite-water fractionation of BERTENRATH et al. (1973). Since the Shirataki mine is situated on the higher metamorphic side of biotite isograd (Higashino, 1975) and hence lies in the albitebiotite zone, this temperature is consistent with the temperatures estimated from the carbon isotopic fractionation.

Isotopic compositions of carbonates Carbon and oxygen isotopic compositions of 14 samples besides 8 samples mentioned in the previous section, and strontium isotopic ratios of 6 samples were determined to elucidate the origin of marbles.

1) Carbon and oxygen isotopic compositions Carbon and oxygen isotopic compositions are listed in Tables 1 and 2, and illustrated in Fig. 4. 
Of eight marbles (15 data for subsamples) collected from the pelitic sequences, $\delta^{13} \mathrm{C}$ and $\delta^{18} \mathrm{O}$ values range from -1.6 to $+2.1 \%$ o and from +14.5 to $+15.7 \%$, respectively. These $\delta^{13} \mathrm{C}$ values are in the range of typical sedimentary carbonate values of KEITH and WEBER (1964). The $\delta^{18} \mathrm{O}$ values, however, are limited in a narrow range and evidently lower than those of the typical sedimentary carbonates. These marbles probably exchanged oxygen isotopes with metamorphic fluid or surrounding silicates during the metamorphism, and hence their $\delta^{18} \mathrm{O}$ values were lowered (RYE et al., 1976; SHIEH and TAYLOR 1969; WADA, 1977). The Matsuno samples show a constant $\delta^{18} \mathrm{O}$ value of $+14.6 \pm 0.1 \%$, being more strongly depleted in ${ }^{18} \mathrm{O}$ than the Fujiwara and Hadeba samples $\left(\delta^{18} \mathrm{O}=+15.3 \pm 0.3 \%\right.$ o $)$.

Marbles intercalated in basic schists also have $\delta^{13} \mathrm{C}$ values similar to the typical sedimentary carbonate values.

A marble from quartz schist has $\delta^{13} \mathrm{C}$ and $\delta^{18} \mathrm{O}$ values similar to those of the typical sedimentary carbonates, and the $\delta^{18} \mathrm{O}$ value is distinctly higher than those of the marbles from pelitic and basic schists. Since this marble occurs as a relatively large mass in the quartz schist (HIDE, pers. com. 1980), it is assumed that the rock body of the marble was too large to change its isotopic composition by the ex-

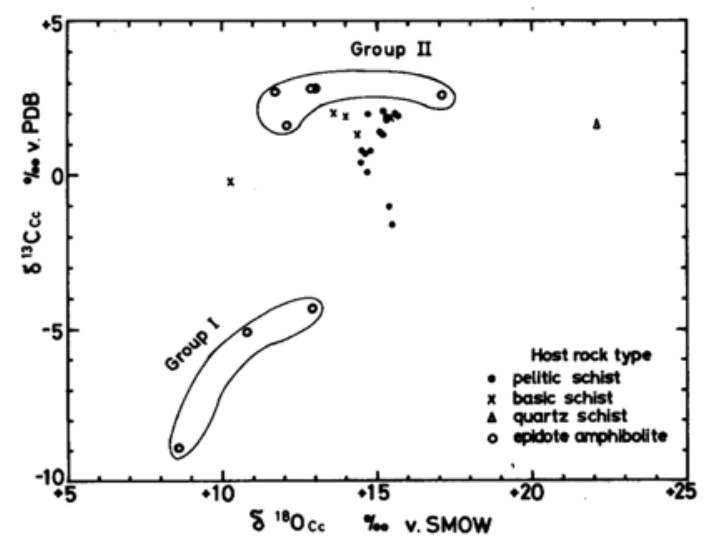

Fig. 4 Relationship between carbon and oxygen isotopic compositions of marbles collected from the Sanbagawa metamorphic terrain, central Shikoku. change reaction with metamorphic fluid during the metamorphism. The sample may have held the original $\delta^{18} \mathrm{O}$ value.

All the marbles collected from crystalline schists, thus, have $\delta^{13} \mathrm{C}$ values in the range of the typical sedimentary carbonates. As mentioned in the previous section, carbon isotopic exchange reaction between calcite and graphite is considered to have occurred in marbles of the pelitic schists. Because of the low graphite content of marbles, however, the carbon isotopic composition of calcite did not disproportionately change during the isotopic exchange reaction. These marbles seem to have originally precipitated from sea water.

Both $\delta^{13} \mathrm{C}$ and $\delta^{18} \mathrm{O}$ values of eight marbles collected from the Tonaru and Iratsu epidote amphibolite masses are varied $\left(\delta^{13} \mathrm{C}=-8.9\right.$ to $+2.8 \%$ 。 and $\delta^{18} \mathrm{O}=+8.6$ to $+17.1 \%$ o). These samples can be classified into two groups with different ranges of $\delta^{13} \mathrm{C}$ values. Group I which includes the samples AE04, 05 and 07, is characterized by negative $\delta^{13} \mathrm{C}$ values $(-4.3$ to $-8.9 \%$ ). On the other hand, group II (samples AE01, 02, 03, 06 and 08) has $\delta^{13} \mathrm{C}$ values of +1.6 to $+2.8 \%$ o, which are similar to those of marbles in crystalline schists.

2) Strontium isotopic ratios Strontium isotopic ratios are also listed in Tables 1 and 2 . Rubidium content of marbles is usually negligible (HeIER and BILlings, 1969), and hence we regard the strontium isotopic ratios $\left({ }^{87} \mathrm{Sr} /{ }^{86} \mathrm{Sr}\right)$ listed in these tables as the ratios when these marbles formed.

Strontium isotopic ratios of two samples collected from pelitic schists (Hadeba and Matsuno) are 0.70705 and 0.70804. A sample which came from a quartz schist has a value of 0.70731 . These three isotopic values fall in the range of pre-Tertiary sea water reported by Peterman et al. (1970). This is consistent with the conclusion that the marbles in crystalline schists have precipitated from sea water. The ${ }^{87} \mathrm{Sr} /{ }^{86} \mathrm{Sr}$ ratios of three marbles (sampels EA01, 04 and 06) collected from the epidote amphibolite masses are $0.70697,0.70522$ and 0.70664 (Table 2). Sample EA04, which be- 
Table 5. Strontium and rubidium isotopic data for epidote amphibolites and eclogites in the Iratsu mass of the Sanbagawa metamorphic terrain, central Shikoku.

\begin{tabular}{llcccc} 
Sample No. & \multicolumn{1}{c}{ Rock type } & $\mathrm{Sr}(\mathrm{ppm})$ & $\mathrm{Rb}(\mathrm{ppm})$ & ${ }^{87} \mathrm{Rb} /{ }^{86} \mathrm{Sr}$ & ${ }^{87} \mathrm{Sr} /{ }^{86} \mathrm{Sr}$ \\
$7-22-17$ & Epidote amphibolite & 719 & 7.60 & 0.0306 & $0.70462 \pm 0.00006$ \\
$7-23-23$ & Epidote amphibolite & 567 & 9.72 & 0.0493 & $0.70520 \pm 0.00005$ \\
$7-23-13$ & Epidote amphibolite & 495 & 1.544 & 0.00902 & $0.70436 \pm 0.00009$ \\
$7093 \mathrm{~K}$ & Epidote amphibolite & 356 & 4.14 & 0.0337 & $0.70462 \pm 0.00006$ \\
$7055 \mathrm{a}$ & Epidote amphibolite & 590 & 1.174 & 0.00576 & $0.70447 \pm 0.00012$ \\
$7-23-2$ & Epidote amphibolite & 480 & - & - & $0.70447 \pm 0.00006$ \\
No. 1 & Zoisite rock & 620 & - & - & $0.70433 \pm 0.00008$ \\
Gon. No. 2 & Hornblende eclogite & - & 26.2 & - & $0.70481 \pm 0.00009$ \\
Gon. No. 7 & Quartz eclogite & 76.6 & 8.00 & 0.302 & $0.70472 \pm 0.00014$ \\
Gon. Chi. No. 8 & Hornblende eclogite & 132.8 & 1.169 & 0.0255 & $0.70624 \pm 0.00009$ \\
Gon. No. 5 & Quartz eclogite & 74.7 & 12.26 & 0.471 & $0.70446 \pm 0.00005$ \\
70072102 & Eclogite & 201.0 & 9.97 & 0.1436 & $0.70400 \pm 0.00011$
\end{tabular}

Unpublished data by T., YANAGI, K. YOKOYAMA and S. BANNO.

longs to the group I according to the $\delta^{13} \mathrm{C}$ criteria, has low ${ }^{87} \mathrm{Sr} /{ }^{86} \mathrm{Sr}$ ratio being close to the values of the amphibolites and eclogites of the Iratsu mass (Table 5). On the other hand, samples EA01 and 06 (group II) have intermediate ${ }^{87} \mathrm{Sr} /{ }^{86} \mathrm{Sr}$ ratios between the Iratsu mass and the marbles in crystalline schists.

Origin of marbles in epidote amphibolite masses As discussed in the previous section, the marbles in epidote amphibolites are classified into two groups with different carbon isotopic compositions. Marbles of group I are characterized by negative $\delta^{13} \mathrm{C}$ values and low ${ }^{87} \mathrm{Sr} /{ }^{86} \mathrm{Sr}$ ratios. Their carbon and oxygen isotopic compositions fall in the range of carbonates in granitic, mafic and ultramafic igneous rocks (HoEFs, 1973; FUEX and BAKER, 1973). The $\delta^{13} \mathrm{C}$ values are also similar to those of magmatic or deep-seated carbons represented by carbonatites and carbonates associated with kimberlites (DEINEs and Gold, 1973; Suwa et al., 1975). Then it follows that some magmatic or deep-seated carbon may have controlled mainly the carbon isotopic compositions of the group I marbles.

As pointed out by several authors (SHIEH and TAYLOR, 1969; TAYLOR and O'NEI, 1977; WADA, 1978), it is expected that carbon isotopic compositions of residual calcite usually change towards negative values during decarbonation reactions. Therefore, we should evaluate a possibility that the negative $\delta^{13} \mathrm{C}$ values of the group I marbles have resulted from some decarbonation reactions during the Sanbagawa metamorphism. If the Sanbagawa marbles were widely affected by the decarbonation reactions, however, the negative $\delta{ }^{13} \mathrm{C}$ value should be observed in marbles commonly irrespective of their modes of occurrence. As the marbles having negative $\delta^{13} \mathrm{C}$ values are found limitedly in the epidote amphibolite masses, decarbonation reactions are probably not a main mechanism to control the carbon isotopic composition of the marbles.

Furthermore, the ${ }^{87} \mathrm{Sr} /{ }^{86} \mathrm{Sr}$ ratios of the group I marble (EA04) fall in the range of those of the host epidote amphibolite masses, showing a marked contrast with high ${ }^{87} \mathrm{Sr} /{ }^{86} \mathrm{Sr}$ ratios of marbles in the crystalline schists. This implies that the group I marbles were probably formed having an intimate genetic relation to their host epidote amphibolite masses. Taking into account the negative $\delta^{13} \mathrm{C}$ values and low ${ }^{87} \mathrm{Sr} /$ ${ }^{86} \mathrm{Sr}$ ratios of the group I marbles, we propose two possible sources of these marbles. One is that these marbles precipitated directly from a hydrothermal solution, which might be related with magmatism which formed the original layered gabbros. Another possible interpretation is that they were derived from magmatic or deep-seated carbonates segregated from the host epidote amphibolite masses during the Sanbagawa metamorphism. Although we have 
little petrologic and mineralogic data to discuss which of these two is more responsible for the formation of the group I marbles, we may safely say that these marbles have isotopic characteristics similar to those of magmatic or deep-seated carbonates, and are different from sedimentary ones like those in crystalline schists.

Group II marbles from epidote amphibolite masses have isotopic compositions similar to those of the typical sedimentary carbonates.

We can not consider that such high $\delta^{13} \mathrm{C}$ values were derived from magmatic or deep-seated carbonates. It may be worthy to mention that all the marbles of the group II were collected near the boundary between the epidote amphibolites and the surrounding crystalline schists (cf. Fig. 1b). BANNo et al., (1976), YoKoYama (1980) and ENAMI (1982) showed that the Tonaru and Iratsu epidote amphibolite masses have been subjected to the Sanbagawa progressive metamorphism with the surrounding schists. Thus, it is possible that these marbles precipitated from metamorphic fluid with high $\delta^{13} \mathrm{C}$ which has segregated from sedimentary sequences and permeated along the lithologic boundary. Another possible explanation is that these marbles were originally co-genetic with those of the group I but their isotopic compositions changed towards higher $\delta^{13} \mathrm{C}$ values during the Sanbagawa metamorphism.

MINAMISHIN et al. (1979) reported the Rb$\mathrm{Sr}$ whole rock isochron of $116 \pm 10 \mathrm{Ma}$ with an initial ${ }^{87} \mathrm{Sr} /{ }^{86} \mathrm{Sr}$ ratios of 0.7066 for pelitic schists in the albite-biotite zone (biotite zone of Higash INO, 1975) of the Asemi river area in central Shikoku (cf. Fig. la). They suggested that the whole rock age does not show the age of sedimentation, but may represent the final stage of dehydration reaction (the last period of the Sanbagawa progressive metamorphism). They also pointed out that the ${ }^{87} \mathrm{Sr} /{ }^{86} \mathrm{Sr}$ initial ratio may indicate the isotopic composition equilibrated with metamorphic fluid escaping from the pelitic sequences during the final stage of dehydration reactions in the Sanbagawa metamorphism. This implies that regional exchange of isotopic compositions took place throughout crystalline schist sequences during metamorphism. Based on these strontium data, we conclude that the high $\delta^{13} \mathrm{C}$ values of the group II marbles have resulted from re-equilibration of group I marbles with metamorphic fluid segregated from the surrounding pelitic sequences during the Sanbagawa metamorphism. This is in accord with the fact that the ${ }^{87} \mathrm{Sr} /{ }^{86} \mathrm{Sr}$ ratios of the group II marbles are close to the initial ${ }^{87} \mathrm{Sr} /{ }^{86} \mathrm{Sr}$ ratio of the pelitic schists reported by Minamishin et al. (1979). The group II marbles occur only in the marginal parts of the epidote amphibolite masses, thus the reequilibration of isotopic composition was probably promoted by the metamorphic fluid permeating along the lithologic boundaries between the epidote amphibolites and the surrounding schists.

Acknowledgements-We would like to express our sincere thanks to Prof. K. HIDE of Hiroshima University for offering his samples (BS03 05 and QS01) and beneficial personal communications. We deeply thank Dr. $K$. YoKoYAMA of National Science Museum, and Prof. S. BANNO of Kyoto University for permitting us to publish their unpublished data. Profs. N. NAKAI and K. SUWA and Dr. K. SUZUKI of Nagoya University are gratefully acknowledged for their warm encouragements.

\section{REFERENCES}

BanNo, S. (1964) Petrologic studies on Sanbagawa crystalline schists in the Bessi-Ino district, central Shikoku, Japan. J. Fac. Sci. Univ. Tokyo, Sec. II 15, 203-319.

BanNo, S., Yokoyama, K., IWATA, O. and TERASHIMA, S. (1976) Genesis of epidote amphibolite masses in the Sanbagawa metamorphic belt of central Shikoku. J. Geol. Soc. Japan, 82, 199-210 (in Japanese with English abstract).

BanNo, S., Higashino, T., OTSUki, M., Itaya, T. and NAKAJIMA, T. (1978) Thermal structure of the Sanbagawa metamorphic belt in central Shikoku. J. Phys. Earth 26, suppl. 345-356.

BERTENRATH, R., FRIEDRICHSEN, H. and HELlNER, E.E. (1973) Die Fractionierung der Sauerstoffisotope ${ }^{18} \mathrm{O}$ und ${ }^{16} \mathrm{O}$ im System Magnetit/Wasser. Fortschr. Mineral. 50, Beih. 3, 32-33.

BOTTINGA, Y. (1969) Calculation of fractionation factors for carbon and oxygen isotope exchange in the system calcite-carbon dioxide-graphite-methane 
-hydrogen-water vapor. Geochim. Cosmochim. Acta $33,49-64$.

Clayton, R.N., O'NeIL, J.R. and MAYEDA, T.K. (1972) Oxygen isotope exchange between quartz and water. J. Geophy. Res. 77, 3057-3067.

CRAIG, H. (1957) Isotopic standards for carbon and oxygen and correction factors for mass-spectrometric analysis of carbon dioxide. Geochim. Cosmochim. Acta 12, 133-149.

CraIG, H. (1961) Standard for reporting concentrations of deuterium and oxygen-18 in natural waters. Science 133, 1833-1834.

DEINES, P. and GoLD, D.P. (1973) The isotopic composition of carbonatite and kimberlite carbonates and their bearing on the isotopic composition of deep-seated carbon. Geochim. Cosmochim. Acta 37, 1709-1733.

ENAMI, M. (1980) Petrology of the Fujiwara mass and the surrounding pelitic schists in the Sanbagawa metamorphic belt, central Shikoku. J. Geol. Sec. Japan 86, 461-473 (in Japanese with English abstract).

ENAMI, M. (1982) Oligoclase-biotite zone of the Sanbagawa metamorphic terrain in the Bessi district, central Shikoku, Japan. J. Geol. Soc. Japan 88, 887-900 (in Japanese with English abstract).

ENAMI, M. (1983) Petrology of pelitic schists in the oligoclase-biotite zone of the Sanbagawa metamorphic terrain, Japan: phase equilibria in the highest grade zone of a highest grade zone of a high-pressure intermediate type of metamorphic belt. J. Metamor. Geol. 1, 141-161.

FRIEDMAN, I. and O'NEIL, J.R. (1977) Compilation of stabale isotope fractionation factors of geochemical interest. In: Data of geochemistry, 6th Ed. Geol. Surv. Prof. Paper 440KK.

FUEX, A.N. and BAKER, D.R. (1973) Stable carbon isotopes in selected granitic, mafic and ultramafic igneous rocks. Geochim. Cosmochim. Acta 37, 2509-2521.

HEIER, K.S. and BILlingS, G.K. (1969) Abundance in common sediments and sedimentary rock types. In Handbook of geochemistry, Chap. XXXVII/K (ed. K.H. WEDEPOHL). Springer, Berline-Heidelberg-New York.

HIDE, K. (1954) Geological structure of the Shirataki mining district, Kochi Prefecture. Geol. Rept. Hiroshima Univ. 4, 48-83 (in Japanese with English abstract).

HIDE, K. (1961) Geologic structure and metamorphism of the Sanbagawa crystalline schists of the Bessi-Shirataki mining district in Shikoku, Southwest Japan. Geol. Rept. Hiroshima Univ. 9, 1-87 (in Japanese with English abstract).

HoEFS, J. (1973) Ein Beitrag zur Isotopengeochemie des Kohlenstoffs in magmatischen Gesteinen. Contrib. Mineral. Petrol. 41, 277-300.

HOEFS, J. (1980) Stable isotope geochemistry. Springer-Verlag, Berline-Heidelberg-New York.

HOEFS, J. and FREY, M. (1976) The isotopic composition of carbonaceous matter in a metamorphic profile from the Swiss Alps. Geochim. Cosmochim. Acta 40, 945-951.

Higashino, T. (1975) Biotite zone of Sanbagawa metamorphic terrain in the Shiragayama area, central Shikoku, Japan. J. Geol. Soc. Japan 81, 653-670 (Japanese with English abstract).

Higashino, T., Hide, K. and BanNo, S. (1977) Metamorphic zone map of the Sanbagawa belt in Shikoku island and Kii peninsula, Japan. The Sanbagawa Belt (ed. K. HIDE) Hiroshima Univ. Press, 201-206 (in Japanese with English abstract).

KAWACHI, Y., LANDIS, C.A. and WATANABE, T. (1973) Pillow lava, agglutinate and associated volcanogenic rocks in spotted greenschist, blueschists and epidoteamphibolites of the Sambagawa belt, central Shikoku, Japan. J. Geol. Soc. Japan 79, 745-753 (in Japanese with English abstract).

KAWACHI, Y., WATANABE T. and LANDIS, C.A. (1982) Origin of mafic volcanogenic schists and related rocks in the Sanbagawa belt, Japan. J. Geol. Soc. Japan 88, 797-817.

KEITH, M.L. and WEBER, J.N. (1964) Isotopic composition and environmental classification of selected limestones and fossils. Geochim. Cosmochim. Acta 28, 1787-1816.

LANDIS, C.A. (1971) Graphitization of dispersed carbonaceous material in metamorphic rocks. Contrib. Mineral. Petrol. 30, 34-45.

MCCREA, J.M. (1950) On the isotopic chemistry of carbonates and a paleotemperature scale. J. Chem. Phys. 18, 849-857.

Minamishin, M., Yanagi, T. and Yamaguchi, M. (1979) Rb-Sr whole rock age of the Sanbagawa metamorphic rocks in central Shikoku, Japan. In: Isotope geosciences of Japanese Islands (ed. by M. YAMAGUCHI) 68-71 (in Japanese)

MiYASHIRO, A. (1961) Evolution of metamorphic belts. J. Petrol. 2, 277-311.

Peterman, Z.E., HedGe, C.E. and Tourtelot, H.A. (1970) Isotopic composition of strontium in sea water throughout Phanerozoic time. Geochim. Cosmochim. Acta 34, 105-120.

Pineau, F., Latouche, L. and JaVoy, M. (1976) L'origine du graphite et les fractionnements isotopiques du carbone dans les marbres métamorphiques des Gour Oumelalen (Ahaggar, Algérie), des Adirondacks (New-Jersey, U.S.A.), et du Damara (Namibie, Sud-Ouest africain). Bull. Soc. Geol. Fr. 18, 1713-1723. 
RYE, R.O., SCHUILING, R.D., RYE, D.M. and JANSEN J.B.H. (1976) Carbon, hydrogen, and oxygen isotope studies of the regional metamorphic complex at Naxos, Greece. Geochim. Cosmochim. Acta 40, 1031-1049.

SHIEH, Y.N. and TAYLOR, H.P.JR. (1969) Oxygen and carbon isotope studies of contact metamorphism of carbonate rocks. J. Petrol. 10, 307-331.

SUWA, K., OANA, S., WADA, H. and OSAKI, S. (1975) Isotope geochemistry and petrology of African carbonatites. Phys. Chem. Earth 9, 735-746.

TAGIRI, T. and TSUBOI, S. (1979) Mixed carbonaceous material in Mesozoic shales and sandstones from the Yamizo mountain-system, Japan. Ganseki Kobutsu Kosho Gakkaishi 74, 47-56.

TAKASU, A. and MAKINO, K. (1980) Stratigraphy and geologic structure of the Sanbagawa metamorphic belt in the Bessi district, Shikoku, Japan-Reexamination of the recumbent fold structures-. Chikyu Kagaku, (Earth Science) 34, 16-26 (in Japanese with English abstact).

TAYLOR, B.E. and O'NEIL, J.R. (1977) Stable isotope studies of metasomatic $\mathrm{Ca}-\mathrm{Fe}-\mathrm{Al}-\mathrm{Si}$ skarns and associated metamorphic and igneous rocks, Osgood Mountains, Nevada. Contrib. Mineral. Petrol. 63, $1-49$.

TAYLOR, H.P.JR. and COLEMAN, R.G. (1968) $\mathrm{O}^{18} /$ $\mathrm{O}^{16}$ ratios of coexisting minerals in glaucophanebearing metamorphic rocks. Geol. Soc. Am. Bull. 79, 1727-1756.

VALLEY, J.W. and O'NeIL, J.R. (1981) ${ }^{13} \mathrm{C} /{ }^{12} \mathrm{C}$ exchange between calcite and graphite: a possible thermometer in Grenville marbles. Geochim. Cosmochim. Acta 45, 411-419.

WADA, H. (1977) Isotopic studies of graphite in metamorphosed carbonate rocks of central Japan. Geochem. J. 11, 183-197.

WADA, H. (1978) Carbon isotope study on graphite and carbonate in the Kamioka mining district, Gifu Prefecture, central Japan, in relation to the role of graphite in the pyrometasomatic ore deposition. Mineral. Deposita (Berl.) 13, 201-220.

WADA, $\mathrm{H}$. and OANA, S. (1975) Carbon and oxygen isotope studies of graphite bearing carbonates in the Kasuga area, Gifu Prefecture, central Japan. Geochem. J. 9, 149-160.

WADA, H. and SUZUKI, K. (1983) Carbon isotopic thermometry calibrated by dolomite-calcite solvus temperatures. Geochim. Cosmochim. Acta 47, 697-706.

Watanabe, T. and KaWACHI, Y. (1975) Some aspects on the nature of original rocks, structure and metamorphism of the Sanbagawa Belt. Ass. Geol. Collab. Japan Monogr. No. 19, 81-87 (in Japanese with English abstract).

YOKOYAMA, K. (1980) Nikubuchi peridotite body in the Sanbagawa metamorphic belt; Thermal history of the Al-pyroxene-rich suite peridotite body in high pressure metamorphic terrain. Contrib. Mineral. Petrol. 73, 1-13.

YUSA, Y. (1976) A rapid method for quantitative microprobe analysis of carbonate minerals. Ganseki Kobutsu Kosho Gakkaishi 71, 120-124 (in Japanese with English abstract). 